\title{
Effect of Ibuprofen on Skeletal Muscle of Dysferlin-Null Mice
}

\author{
Alyssa F. Collier, ${ }^{1,2}$ Jessica Gumerson,, ${ }^{1,3}$ Kimmo Lehtimäki, Jukka Puoliväli, Jace W. Jones, \\ Maureen A. Kane, Sankeerth Manne, Andrea O'Neill, Hillarie P. Windish, Toni Ahtoniemi, \\ Bradley A. Williams, Douglas E. Albrecht, and Robert J. Bloch \\ Department of Physiology, University of Maryland School of Medicine, Baltimore, Maryland (A.F.C., J.G., S.M., A.O'N., R.J.B.); \\ Charles River Laboratories, Kuopio, Finland (K.L., J.P., T.A.); Mass Spectrometry Center, Department of Pharmaceutical \\ Sciences, University of Maryland School of Pharmacy, Baltimore, Maryland (M.A.K., J.W.J.); and Jain Foundation, Seattle, \\ Washington (H.P.W., B.A.W., D.E.A.)
}

Received August 2, 2017; accepted December 21, 2017

\section{ABSTRACT}

Ibuprofen, a nonsteroidal anti-inflammatory drug, and nitric oxide (NO) donors have been reported to reduce the severity of muscular dystrophies in mice associated with the absence of dystrophin or $\alpha$-sarcoglycan, but their effects on mice that are dystrophic due to the absence of dysferlin have not been examined. We have tested ibuprofen, as well as isosorbide dinitrate (ISDN), a NO donor, to learn whether used alone or together they protect dysferlin-null muscle in $\mathrm{A} / \mathrm{J}$ mice from large strain injury (LSI) induced by a series of high strain lengthening contractions. Mice were maintained on chow containing ibuprofen and ISDN for 4 weeks. They were then subjected to LSI and maintained on the drugs for 3 additional days. We measured loss of torque immediately following injury and at day 3 postinjury, fiber necrosis, and macrophage infiltration at day 3 postinjury, and serum levels of the drugs at the time of euthanasia. Loss of torque immediately after injury was not altered by the drugs. However, the torque on day 3 postinjury significantly decreased as a function of ibuprofen concentration in the serum (range, $0.67-8.2 \mu \mathrm{g} / \mathrm{ml}$ ), independent of ISDN. The effects of ISDN on torque loss at day 3 postinjury were not significant. In long-term studies of dysferlinopathic BIAJ mice, lower doses of ibuprofen had no effects on muscle morphology, but reduced treadmill running by $40 \%$. Our results indicate that ibuprofen can have deleterious effects on dysferlin-null muscle and suggest that its use at pharmacological doses should be avoided by individuals with dysferlinopathies.

\section{Introduction}

Muscular dystrophies are diseases of skeletal muscle in which muscle fibers are lost and replaced by fibrotic and adipose tissue. Treatments for the muscular dystrophies have for many years been largely limited to corticosteroids and related drugs (Drachman et al., 1974; Walter et al., 2013; reviewed in Griggs et al., 2013; Matthews, et al., 2016), which suppress the inflammation that occurs when muscle fibers are damaged. Although more targeted therapies are now being developed (e.g., Mendell et al., 2013, 2016; Nelson et al., 2016; Tabebordbar et al., 2016), alternative anti-inflammatory drugs that avoid some of the side effects of the corticosteroids have also been tested. Most of these tests have used animal

This work has been supported in part by the University of Maryland Baltimore, School of Pharmacy Mass Spectrometry Center [SOP1841IQB2014], by a traineeship to J.G. from the National Institutes of Health [Grant T32 AR 007592, Dr. M. Schneider, P.I.], by a generous donation by the Williams family, and by the Kahlert Foundation, the Jain Foundation, and grants to R.J.B. from the Jain Foundation and the National Institutes of Health [Grant RO1 AR064268].

${ }^{1}$ A.F.C. and J.G. contributed equally to this work.

${ }^{2}$ Current affiliation: Program in Physical Therapy, Washington University School of Medicine, St. Louis, Missouri.

${ }^{3}$ Current affiliation: National Eye Institute, Bethesda, Maryland.

https://doi.org/10.1124/jpet.117.244244. models of Duchenne muscular dystrophy (DMD), the most common of the dystrophies in the human population. Drugs tested include remicade, amitriptyline, resveratrol, eicosopentanoic acid, bortezomib, and VBP15, a modified steroid with membrane-stabilizing activity (Grounds and Torrisi, 2004; Araujo et al., 2013; Carvalho et al., 2013; Heier et al., 2013; Ermolova et al., 2014; Gordon et al., 2014; Manning et al., 2014). In addition, Clementi et al. have tested the potential of ibuprofen, used alone or in combination with a nitric oxide (NO) donor, such as isosorbide dinitrate (ISDN), in murine models of muscular dystrophies caused by $\alpha$-sarcoglycanopathy $\left(\mathrm{Sgca}^{-1-}\right)$ and dystrophinopathy ( $m d x$ ) (Brunelli et al., 2007; Sciorati et al., 2010). Based on their results in mice, Clementi et al. have begun to test the potential benefits of a drug combining the effects of ibuprofen and ISDN for use in boys with DMD (Cossu et al., 2014).

Limb girdle muscular dystrophy type 2B (LGMD2B) and Miyoshi myopathy (MMD1) are autosomal recessive diseases linked to mutations in the dysferlin gene (DYSF), located on human chromosome 2p13 (Liu et al., 1998; Nigro and Savarese, 2014). LGMD2B and MMD1 typically manifest in the teen years, and, although the penetrance of the mutations can vary, most affected individuals are dependent on wheelchairs for mobility by the age of 45 . Disease progression is aggravated by

ABBREVIATIONS: DMD, Duchenne muscular dystrophy; ISDN, isosorbide dinitrate; LGMD2B, limb girdle muscular dystrophy type 2B; LSI, large strain injury; MMD1, Miyoshi myopathy; MRI, magnetic resonance imaging; NO, nitric oxide; TA, tibialis anterior. 
exercise (Klinge et al., 2008; Angelini et al., 2011), and, as in other dystrophies, LGMD2B and MMD1 are commonly associated with inflammation of muscle (e.g., McNally et al., 2000; Gallardo et al., 2001; Wenzel et al., 2005; Yin et al., 2015; reviewed in Mariano et al., 2013). Steroid treatment to reduce inflammation can be detrimental in dysferlinopathies, however (Walter et al., 2013; but see Quattrocelli et al., 2017). Studies in animal models indicate that, as in humans, exercise can significantly damage dysferlin-null muscle (Lovering et al., 2007; Roche et al., 2010, 2012; Lostal et al., 2012; Biondi et al., 2013), leading to necrotic death of muscle fibers and a large increase in inflammatory cell infiltrates, primarily $\mathrm{CD} 8^{+}$macrophages (Roche et al., 2008, 2010, 2015). Evidence also suggests that the inflammatory response is aggravated in mice with monocytes lacking dysferlin (Nagaraju et al., 2008). In this study, we address the possibility that ibuprofen, used alone or in combination with ISDN, can ameliorate the loss of muscle fibers in injured dysferlin-null mice. Our results suggest that, unlike the effects of these drugs on other murine models of muscular dystrophy, ibuprofen used with or without ISDN can have a deleterious effect on the muscles of two strains of dysferlinopathic mice.

\section{Materials and Methods}

Mice and Feeding. All A/J and C57BL/6J mice used in these studies were purchased from The Jackson Laboratory (Bar Harbor, ME). B6.A-Dysf $f^{p r m} /$ GeneJ (BlAJ) mice were a gift of the Jain Foundation. All animal experiments were carried out according to the National Institutes of Health guidelines for the care and use of laboratory animals. Protocols involving A/J mice were approved by the Institutional Animal Care and Use Committee, University of Maryland School of Medicine. Protocols involving BlAJ and C57BL/6J mice were approved by the National Animal Experiment Board, Finland. $\mathrm{A} / \mathrm{J}, \mathrm{BlAJ}$, and $\mathrm{C} 57 \mathrm{BL} / 6 \mathrm{~J}$ mice were 3 and 5 months of age at the beginning of each study, respectively. Males only were used in studies of A/J. Both males and females were used in studies of BlAJ and C57BL/6J; no significant differences in the responses of males and females were observed.

$\mathrm{A} / \mathrm{J}$ mice were identified with tail tattoos and were weighed weekly over the 4-week study period. Several mice were housed per cage. The daily food consumption rate was measured per cage by weighing the food weekly and dividing by the sum of all the weights of the mice in the cage and the number of days, typically 7 . This was then normalized for consumption by a typical $25 \mathrm{~g}$ mouse to give food consumed per day per $25 \mathrm{~g}$ mouse. Drug intake was calculated similarly and then normalized to milligrams per kilogram per day.

Short-Term Studies. Short-term studies, lasting 4 weeks, were performed with $\mathrm{A} / \mathrm{J}$ mice. The first and third experimental cohorts used 12 mice each ( $n=3 /$ drug or drug combination, and for control), cohort 2 used 14 mice ( $n=3 /$ drug or drug combination; $n=5$ for control), and cohort 4 used 16 mice $(n=4 /$ drug or drug combination, and for controls). Diets were from Harlan Laboratories (Frederick, $\mathrm{MD}$ ): control (AIN-93G) or a diet that also included ibuprofen, ISDN, or both drugs together. Mouse weight (grams; see above) and remaining food (grams) were measured on days $0,7,14,21$, and 28. Mice were studied further at the end of week 4.

Food consumption rates were estimated as above, based on the reported amount of food consumed by an A/J mouse with a body weight of $25 \mathrm{~g}$ (Bachmanov et al., 2002). Our initial studies used the average doses of $50 \mathrm{mg} / \mathrm{kg}$ per day ibuprofen and $30 \mathrm{mg} / \mathrm{kg}$ per day ISDN, as previously reported (Brunelli et al., 2007; Sciorati et al., 2010). The rate was adjusted across studies in three distinct formulations of chow, which resulted in a range of average daily doses of each drug, alone or in combination (Table 1). For the fourth cohort, the concentrations of drugs were adjusted to deliver an average of $200 \mathrm{mg} / \mathrm{kg}$ per day ibuprofen and $20 \mathrm{mg} / \mathrm{kg}$ per day ISDN.

Over the course of the experiments, three $\mathrm{A} / \mathrm{J}$ mice were lost under anesthesia while undergoing the injury procedure. An additional five mice were excluded from analysis because no drugs could be detected in their sera, due to difficulties in sample preparation. Group numbers for functional analysis were as follows: control ( $n=13)$, ibuprofen ( $n=11)$, ISDN $(n=12)$, and ibuprofen + ISDN $(n=13)$. A total of five mice did not complete the torque study.

Long-Term Studies. Long-term experiments used BlAJ and C57BL/6J mice. They were initiated when the mice were 5 months of age and continued to 12 [magnetic resonance imaging (MRI) studies] and 14 months (all other studies). Nine BlAJ males and seven BlAJ females were treated with ibuprofen, nine BlAJ males and eight BlAJ females served as dysferlinopathic controls, and 10 males and 10 females each of the C57BL/6J strain served as healthy controls. The ibuprofen diet was Teklad Rodent Chow 2016 from Research Diets (New Brunswick, NJ) and contained 0.0125\% ibuprofen by weight. Dosage was in the low range of the doses that we used for A/J to try to minimize any adverse long-term effects of the drug.

Over the course of the studies, one female BlAJ control and two male and three female C57BL/6J controls died. In addition, four BlAJ females treated with ibuprofen developed skin lesions and were euthanized. Two male BlAJ mice, untreated with ibuprofen, were euthanized due to a fight injury and a tumor.

Pharmaceutical Prescriptions. Harlan Laboratories and Research Diets provided the ibuprofen administered in this study as an optional addition to their standard chows. Concentrations in the chow were $0.29-2.1 \mathrm{mg} / \mathrm{kg}$. For the first study of ISDN, we obtained pure ISDN in powder form (Sigma-Aldrich, St. Louis, MO) and used it at $0.18 \mathrm{mg} / \mathrm{kg}$ chow. However, due to lack of availability, the final three studies required a prescription for ISDN $(20 \mathrm{mg}$ tablets, NDC: 007811695; Sandoz, Princeton, NJ) obtained through Veterinary Resources at the University of Maryland School of Medicine. The daily dose rate of ISDN was adjusted to account for the inert ingredients in a single tablet so that the amount of ISDN in powder from a tablet equated to $1 \mathrm{mg}$ pure ISDN. Final concentrations of ISDN in these experiments were $1.8-3.0 \mathrm{mg} / \mathrm{kg}$ chow.

Assays of Drug Levels in Serum. Immediately following the torque measurement on day 3 after large strain injury (LSI; see below), blood was taken from the femoral artery in a $1 \mathrm{ml}$ tuberculin syringe (309659; BD Biosciences, San Jose, CA) coated with heparin sodium solution (400-10; Sagent Pharmaceuticals, Schaumburg, IL). Samples were subjected to centrifugation for 10 minutes at $6000 \mathrm{rpm}$ (Microfuge 18 Centrifuge; Beckman Coulter, Brea, CA), and serum was removed and stored at $-80^{\circ} \mathrm{C}$.

Pharmacological levels of each drug in A/J mice were measured by liquid chromatography-photodiode array detection or liquid chromatography-tandem mass spectrometry. Stock solutions of

TABLE 1

Chow formulations and dosages

\begin{tabular}{lcccccc}
\hline $\begin{array}{c}\text { Short-Term } \\
\text { Cohort No. }\end{array}$ & $\begin{array}{c}\text { Ibuprofen } \\
\text { (mg/g chow) }\end{array}$ & $\begin{array}{c}\text { ISDN (mg/g } \\
\text { chow) }\end{array}$ & $\begin{array}{c}\text { Intended Ibuprofen Dosage } \\
\text { (mg/kg per day) }\end{array}$ & $\begin{array}{c}\text { Estimated Ibuprofen Dosage } \\
\text { (mg/kg per day) }\end{array}$ & $\begin{array}{c}\text { Intended ISDN Dosage } \\
\text { (mg/kg per day) }\end{array}$ & $\begin{array}{c}\text { Estimated ISDN Dosage } \\
\text { (mg/kg per day) }\end{array}$ \\
\hline 1 & 0.289 & 0.177 & 50 & 31.1 & 30.6 & \\
2 & 0.576 & 2.95 & 50 & 25.9 & 30.6 & 17.5 \\
3 & 0.576 & 2.95 & 50 & 29.5 & 30.6 & 19.0 \\
4 & 2.13 & 1.82 & 200 & 191.3 & 20.0 & 9.8 \\
\hline
\end{tabular}


ibuprofen, ISDN, and indomethacin (Sigma-Aldrich) were prepared in water:methanol (1:1, v/v; high-pressure liquid chromatography grade; Fisher Scientific, Pittsburgh, PA). Calibration standards ranging from 0.1 to $200 \mu \mathrm{M}$ ibuprofen or ISDN spiked with $10 \mu \mathrm{M}$ indomethacin (internal standard) were prepared in neat solvent water:methanol $(1: 1, \mathrm{v} / \mathrm{v})$ and in mouse serum. Quality control samples at three concentration levels $(5,50$, and $150 \mu \mathrm{M})$ were also prepared for neat standards and serum samples. Serum samples were prepared where $100 \mu \mathrm{l}$ serum was combined with $10 \mu \mathrm{M}$ indomethacin and $500 \mu \mathrm{l}$ acetonitrile for protein precipitation. The mixture was thoroughly mixed for 30 seconds, followed by centrifugation at $8000 \mathrm{rpm}$ for 10 minutes at $4^{\circ} \mathrm{C}$. Supernatant $(500 \mu \mathrm{l})$ was transferred and dried under a steady stream of nitrogen. The sample was resuspended in $100 \mu$ l water:methanol (1:1, v/v). Liquid chromatography-photodiode array detection analyses were performed on a H-Class Acquity UPLC quaternary liquid chromatography system coupled to a UPLC PDA (photodiode array) Detector (Waters, Milford, MA). The LC separation was performed on a Phenomenex C18 column $(2.1 \times 50 \mathrm{~mm}, 4 \mu \mathrm{m}$; Torrance, CA) operated at $30^{\circ} \mathrm{C}$. Solvents A, B, and C consisted of water, $50 \mathrm{mM}$ ammonium acetate, and methanol, respectively. An isocratic elution consisted of $35 \% \mathrm{~A}, 10 \% \mathrm{~B}$, and $55 \% \mathrm{C}$ with a flow rate of $1 \mathrm{ml} / \mathrm{min}$ for a duration of 4 minutes. The PDA detector was set to monitor $220 \mathrm{~nm}$. The injection volume was $10 \mu \mathrm{l}$.

Plasma was prepared from blood drawn by cardiac puncture that was placed in ice-cold EDTA tubes and subjected to centrifugation at $2000 \mathrm{~g}$ for 10 minutes at $4^{\circ} \mathrm{C}$. Levels of ibuprofen in the plasma of BlAJ mice were measured in $10 \mu \mathrm{l}$ volumes of samples, subjected to precipitation of proteins with $50 \mu \mathrm{l}$ acetonitrile. After centrifugation to remove the precipitate, $40 \mu \mathrm{l}$ each sample was transferred to a clean 96 -well plate, diluted with the same volume of liquid chromatography-mass spectrometry grade water, mixed, and then analyzed with a Shimadzu Nexera instrument (Shimadzu, Tokyo, Japan) equipped with a Shimadzu SIL-AC autosampler and a Chromolith C18-RP-3 column, $3.0 \times 100 \mathrm{~mm}$ (Millipore Sigma, Darmstadt, Germany). Conditions were as follows: injection volume, $5 \mu \mathrm{l}$; flow rate, $1.6 \mathrm{ml} / \mathrm{min}$; mobile phases, liquid chromatography-mass spectrometry grade water, followed by $1 \%$ formic acid in methanol:acetonitrile (1:1); and gradient, $1.00 \mathrm{~min}-$ ute gradient from $10 \%$ to $100 \%$ of the formic acid/methanol/ acetonitrile solution with a total run time of 3.50 minutes. Internal standards and standard curves were run routinely. Mass spectrometry used an AB Sciex QTRAP 6500 (Framingham, MA) instrument, with multiple reaction monitoring with Q1 and Q3 units.

Large Strain Injury. The LSI protocol was performed in vivo on the left tibialis anterior (TA) muscle of each $\mathrm{A} / \mathrm{J}$ mouse, as described (Roche et al., 2008, 2010). Briefly, the leg was fixed in position perpendicular to the tibia with the foot taped to a footplate driven by a stepper motor and the limb pinned through the femur for stability. The foot was forced into plantarflexion through a $90^{\circ}$ arc of motion at $450 \%$, whereas the anterior muscles of the lower hind limb were tetanically stimulated at $150 \mathrm{~Hz}$ for $450 \mathrm{~ms}$ via the peroneal nerve. This was repeated 20 times over 20 minutes. Contractile torque was measured before (day 0-pre), immediately after (day 0 ), and 3 days (day 3 ) after injury to assess susceptibility to the initial injury and recovery thereafter. Mice were euthanized on day 3 after the last measurement of contractile torque, and their TA muscles were snap frozen for morphologic studies. The TA is the predominant ankle dorsiflexor muscle of the hind limb, responsible for $~ 85 \%$ of contractile torque (Lovering et al., 2007), and thus experiences the greatest strain during LSI.

H\&E Staining. Cross sections $16 \mu \mathrm{m}$ in thickness from the midbelly of unfixed, snap-frozen TA muscles were fixed with acetone $\left(-20^{\circ} \mathrm{C}\right)$, air dried, and rinsed with distilled water. Slides were first immersed in hematoxylin (Hematoxylin Solution Gill No. 3, GHS332-1L; Sigma Aldrich) for 3 minutes, and then placed in Scott's Bluing reagent (Scott's Bluing reagent, 6697-32; Ricca Chemical, Pocomoke City, MD) for 1 minute. Slides were then dipped three times into eosin (Eosin Y Solution Alcoholic, HT110132-1L; Sigma Aldrich, St. Louis, MO) and rapidly dipped in $95 \%$ ethanol for a total of 10 times. Sections were washed with a series of distilled water rinses between the different staining steps. Coverslips were mounted with Permount mounting medium (Permount, SP15-100
Toluene Solution UN1294; Fisher Scientific). Sections were observed under light microscopy (20× objective lens, Zeiss Axioscope; Carl Zeiss, Poughkeepsie, NY). Nine centrally located fields were selected randomly for analysis of necrotic fibers, which were identified based on their pale appearance and fragmented myoplasm, with or without invasion by mononuclear cells. Images were analyzed with ImageJ software (NIH). The percentage of total fibers that appear necrotic is presented as mean \pm S.E.M.

Immunofluorescence Labeling. Cross sections (16 $\mu \mathrm{m})$ were fixed with acetone $\left(-20^{\circ} \mathrm{C}\right)$, air dried, rehydrated with phosphatebuffered saline, and placed in Superblock (37515; ThermoFisher Scientific, Waltham, MA) for 1 hour. For labeling of macrophages, sections were incubated overnight at $4^{\circ} \mathrm{C}$ with anti-mouse CD68 (137002; BioLegend, San Diego, CA) diluted in Superblock 1:100, and anti-dystrophin (PA5-32388, Pierce Antibodies from ThermoFisher Scientific) diluted in Superblock 1:200. After washing, Alexa Fluor 488 goat anti-rabbit IgG and Alexa Fluor 568 goat anti-rat IgG (Invitrogen Molecular Probes, from ThermoFisher) were applied for 1 hour. Slides were washed and mounted in Vectashield Mounting Medium with 4',6'-diamidino-2-phenylindole (H-1200; Vector Laboratories, Burlingame $\mathrm{CA}$ ). The number of macrophages per square millimeter of muscle was calculated by averaging the number of macrophages across eight randomly chosen, unique visual fields $(40 \times 1$ 1.4 N.A. Plan-Apo objective; Zeiss LSM510) and then multiplying by a conversion factor (19.75) based on the area of each visual field.

Treadmill Running. Treadmill running of BlAJ mice was assessed with a six-lane treadmill (Exer 3/6 Treadmill; Columbus Instruments, Columbus, $\mathrm{OH}$ ). Mice were habituated to the treadmill and shock grid for 10 minutes, without running. The shock level was adjusted to $0.72 \mathrm{~mA}$. Next, the speed was increased from 0 to $6 \mathrm{~m} / \mathrm{s}$ in 1 minute, and then to $18 \mathrm{~m} / \mathrm{s}$ in increments of $2 \mathrm{~m} / \mathrm{min}$ every 3 minutes (test time $6 \times 3$ minutes $=18$ minutes). Trials were terminated when the speed of $18 \mathrm{~m} / \mathrm{s}$ was reached or if the animal received maximum of 40 shocks or was unable to run. Total test time per mouse was 29 minutes.

Rotarod Test. The ability of BlAJ mice to maintain themselves on a Rotarod (AccuScan Instruments, Columbus, $\mathrm{OH}$ ) was determined 1 week after the completion of treadmill testing. The session included a training trial of 5 minutes at $4 \mathrm{rpm}$ on the rotarod apparatus. After the training, mice were tested for two consecutive accelerating trials of 5 minutes, with the speed changing from 0 to $30 \mathrm{rpm}$, with an intertrial interval of 30 minutes. The latency to fall from the rod was recorded. Mice remaining on the rod for more than 300 seconds were removed, and their time was scored as 300 seconds. Values were combined, and the means \pm S.D. were determined.

Creatine Kinase. The creatine kinase levels were calculated automatically by a Thermo Konelab 20 XTi analyzer, according to the manufacturer's manual and application notes (ThermoFisher Scientific, Clinical Diagnostics, Vantaa, Finland).

Magnetic Resonance Imaging. MRI/magnetic resonance spectroscopy analysis was performed in a horizontal 11.7T magnet with bore size $160 \mathrm{~mm}$, equipped with a gradient set capable of a maximum gradient strength $750 \mathrm{mT} / \mathrm{m}$, and interfaced to a Bruker Avance III console (Bruker Biospin, Ettlingen, Germany). A volume coil (Bruker) was used for transmission and a two-element surface array coil for receiving (Rapid Biomedical, Rimpar, Germany). Isofluraneanesthetized mice $\left(70 \% \mathrm{~N}_{2} \mathrm{O}\right.$ and $30 \% \mathrm{O}_{2}$; flow $300 \mathrm{ml} / \mathrm{min}$, induction with $5 \%$, maintenance $1.5 \%$ ) were fixed to a head holder and positioned in the magnet bore in a standard orientation relative to gradient coils.

To measure muscle volumes, high resolution anatomic images were acquired using a three-dimensional fat-suppressed gradient echo FLASH sequence with the following parameters: time to repeat $=$ $25 \mathrm{~ms}$, echo time $=2.5 \mathrm{~ms}$, flip angle $10^{\circ}$, matrix of $320 \times 192 \times 64$, field of view of $26 \times 20 \times 36 \mathrm{~mm}^{3}$, and two transitions. The same scan was repeated at fat frequency, suppressing the water, to evaluate fat content from the combination of the two scans.

Statistics. All values, unless otherwise stated, are reported as mean \pm S.D. Statistical significance was determined by a two-sample $t$ test; StatsDirect (Cheshire, U.K.) software was used to calculate 
the values for BlAJ and $\mathrm{C} 57 \mathrm{BL} / 6 \mathrm{~J}$ mice. Values of $P<0.05$ were considered statistically significant.

\section{Results}

In previous studies of the effects of muscle injury (Roche et al., 2008, 2010), we established that, like the control mouse to which it was compared, the dysferlin-null A/J mouse loses $\sim 40 \%$ of its contractile torque following a series of high strain lengthening contractions (LSI), but that, unlike the control, $\mathrm{A} / \mathrm{J}$ fails to recover contractile function over the 3-day period following injury. Instead, by day 3 postinjury, A/J muscle loses contractile torque and shows a large increase in number of necrotic fibers and macrophages. We used this assay of muscular function, fiber integrity, and inflammation to assess the ability of ibuprofen and ISDN, which have been shown to benefit mice with other forms of muscular dystrophy (Sciorati et al., 2010), to protect dysferlinopathic muscle against the effects of LSI. Because the dysferlinopathy in A/J mice does not develop significant pathophysiology in the time frame of our studies, we did not use them to examine the long-term effects of ibuprofen and ISDN. Instead, we used the BlAJ mouse, which carries the $\mathrm{A} / \mathrm{J}$ mutation in the $\mathrm{C} 57 \mathrm{BL} / 6$ background, and which shows significant disease progression from the age of 2 months on, to examine long-term effects of ibuprofen on the dystrophic phenotype. We also used BlAJ and not $\mathrm{A} / \mathrm{J}$ mice for measurements of mobility on a treadmill and a rotarod, as A/J mice, being largely immobile, in our hands are not amenable to study with these methods, whereas BlAJ and C57BL/6J controls are much more mobile and perform well in these assays.

\section{Short-Term Studies}

Dosage and Serum Levels. We maintained A/J mice for 4 weeks on chow containing ibuprofen and ISDN, either alone or in combination. Concentrations of the drugs in the chow were adjusted from those used by Sciorati et al. (2010), $50 \mathrm{mg} /$ $\mathrm{kg}$ per day ibuprofen and $30 \mathrm{mg} / \mathrm{kg}$ per day for ISDN (Table 1), to achieve a range of doses at pharmacologically effective serum levels (50-200 $\mathrm{mg} / \mathrm{kg}$ per day to reach $\geq 5 \mu \mathrm{g} / \mathrm{ml}$ for ibuprofen; $20-30 \mathrm{mg} / \mathrm{kg}$ per day to achieve 2 to $3 \mu \mathrm{g} / \mathrm{ml}$ for ISDN). During the 4-week treatment, we measured food consumption (Fig. 1A) and the weights of the mice (Fig. 1B) on each of the chows to ensure that they were eating normally and were not adversely affected by the drugs. Food consumption per mouse was less than that expected based on published values (Bachmanov et al., 2002). Although body weights trended to slightly lower values with ibuprofen in the diet (Fig. 1A), these changes were not significant $(P=0.24)$. Thus, neither the addition of ibuprofen nor ISDN, alone or in combination, led to significant changes in food consumption or average body weight over the time course of our studies.

Measurements of the serum levels of the drugs, determined at the end of the experiment (Fig. 1C), showed that ibuprofen concentrations in different mice varied between 0.7 and 8.2 $\mu \mathrm{g} / \mathrm{ml}($ mean \pm S.D. $=4.5 \pm 2.3 \mu \mathrm{g} / \mathrm{ml})$, and ISDN concentrations varied from 2.8 to $11.6(5.8 \pm 2.9 \mu \mathrm{g} / \mathrm{ml})$. These values changed slightly when the drugs were administered together (Fig. 1C), but the differences were not significant. Ibuprofen and ISDN were undetectable in the sera of untreated control mice (in which the limit of quantification was $0.2 \mu \mathrm{g} / \mathrm{ml}$ ). Body

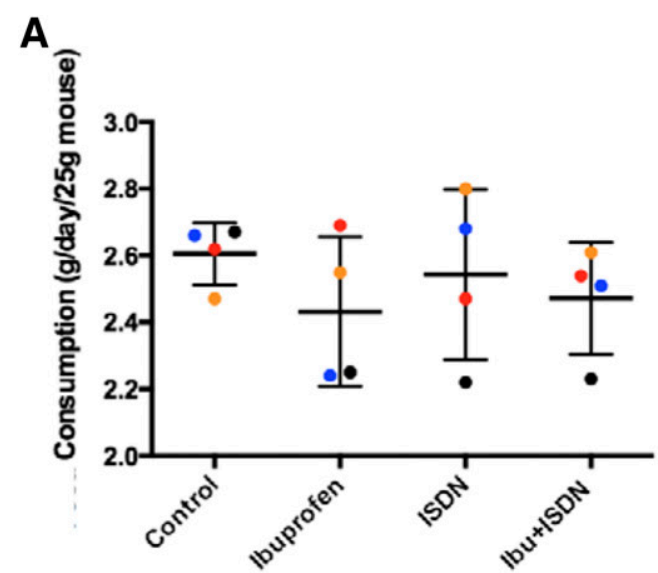

B
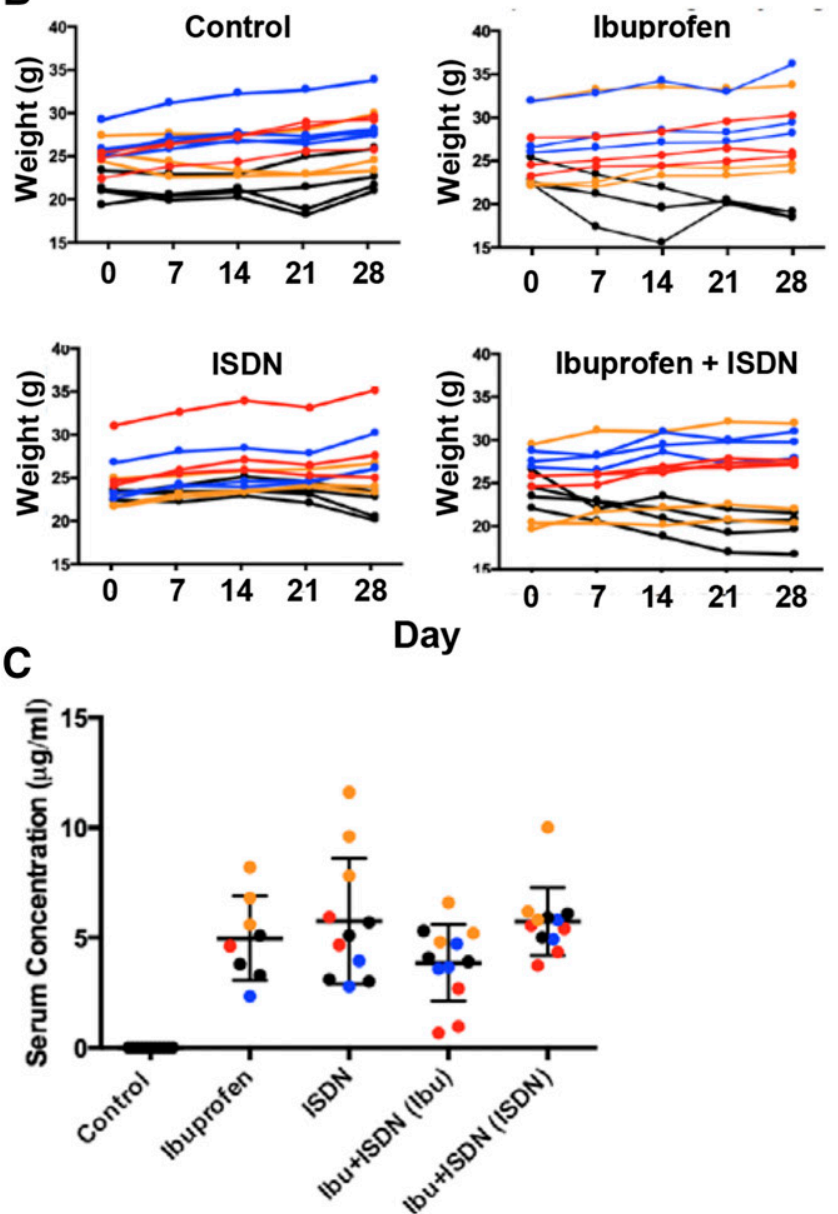

Fig. 1. Dosing A/J mice with ibuprofen and ISDN in the chow. Data are displayed in color to indicate each of the studies we performed. Red, cohort 1 ; blue, cohort 2; orange, cohort 3; black, cohort 4 . Please consult Table 1 for the concentrations of drugs used in each. (A) Food consumed per mouse per day (mean \pm S.D.). (B) Body weights of mice by diet type, plotted for individual mice. Data are expressed as mean \pm S.D. (C) Scattergram of drug concentrations measured in the serum of treated and control A/J mice. The ibuprofen concentrations in mice that were dosed simultaneously with ISDN, and the ISDN concentrations in mice dosed simultaneously with ibuprofen, are given separately. Control values are negligible. The $y$-axes in (A and B) are curtailed. See Materials and Methods for details.

weights did not vary significantly with the serum levels of each drug $(P>0.30$ for all three experimental diets; data not shown). 
Susceptibility to Injury and Recovery. After feeding mice on chows containing ibuprofen, ISDN, or both drugs for 4 weeks, we measured the contractile torque of the hind limb ankle dorsiflexor muscles and then subjected the dorsiflexors to LSI following procedures routine in our laboratory (Roche et al., $2008,2010,2015$ ). We measured the loss of torque in response to LSI, and then replaced the mice in cages with access to the appropriate modified chow for 3 more days, when we again assayed contractile torque and finally euthanized the mice and collected blood and muscle tissue. Our results show that treatment with either drug, or both drugs in combination, had no significant overall effect on the initial torque of the ankle dorsiflexor muscles (Fig. 2A), the loss of torque immediately after injury (Fig. 2, B and D), or the recovery of torque 3 days later (Fig. $2, \mathrm{C}$ and D) after injury. In particular, neither drug promoted recovery on day 3 of the torque lost on day 0 .

We analyzed our data further to determine whether the initial torque, loss of torque immediately after LSI, or recovery of torque at 3 day after LSI varied as a function of the level of either ibuprofen or ISDN in the serum, which differed significantly from mouse to mouse (Fig. 1C). Analysis of initial torque and torque loss on day 0 showed no significant variation with the serum levels of either ibuprofen or ISDN (data not shown). By contrast, lower serum concentrations of ibuprofen were associated with increases in torque on day 3 after LSI, and higher serum concentrations of ibuprofen were associated with decreases in torque on day 3 after LSI. These results were obtained in mice exposed to ibuprofen alone (Fig. 3A; $r^{2}=0.68 ; P=0.012$ ) or to ibuprofen together with ISDN (Fig. 3C; $r^{2}=0.83 ; P<0.0001$ ). Torque levels on day 3 did not correlate consistently with serum levels of ISDN, administered alone (Fig. 3C) or with ibuprofen (Fig. 3D).

Histopathology. We examined frozen sections of the TA muscles from treated and control mice stained with H\&E, to label nuclei and quantify necrotic fibers, and with antibodies to CD68 to quantify macrophages. Sections labeled with H\&E showed evidence of necrotic fibers and accumulations of mononucleate cells in all samples taken at day 3 (Fig. 4Aa, b). Group analysis indicated that muscles exposed to a combination of ibuprofen and ISDN showed a $\sim 25 \%$ decrease in the number of necrotic myofibers compared with controls and to mice treated with ibuprofen alone (Fig. 4B). This decrease was significant. Immunofluorescence labeling with anti-CD68 antibodies identified most of the mononucleate cells as macrophages (Fig. 4Ab), which infiltrate injured A/J muscle at day 3 after LSI (Roche et al., 2010, 2015). Although samples exposed to ibuprofen alone or together with ISDN
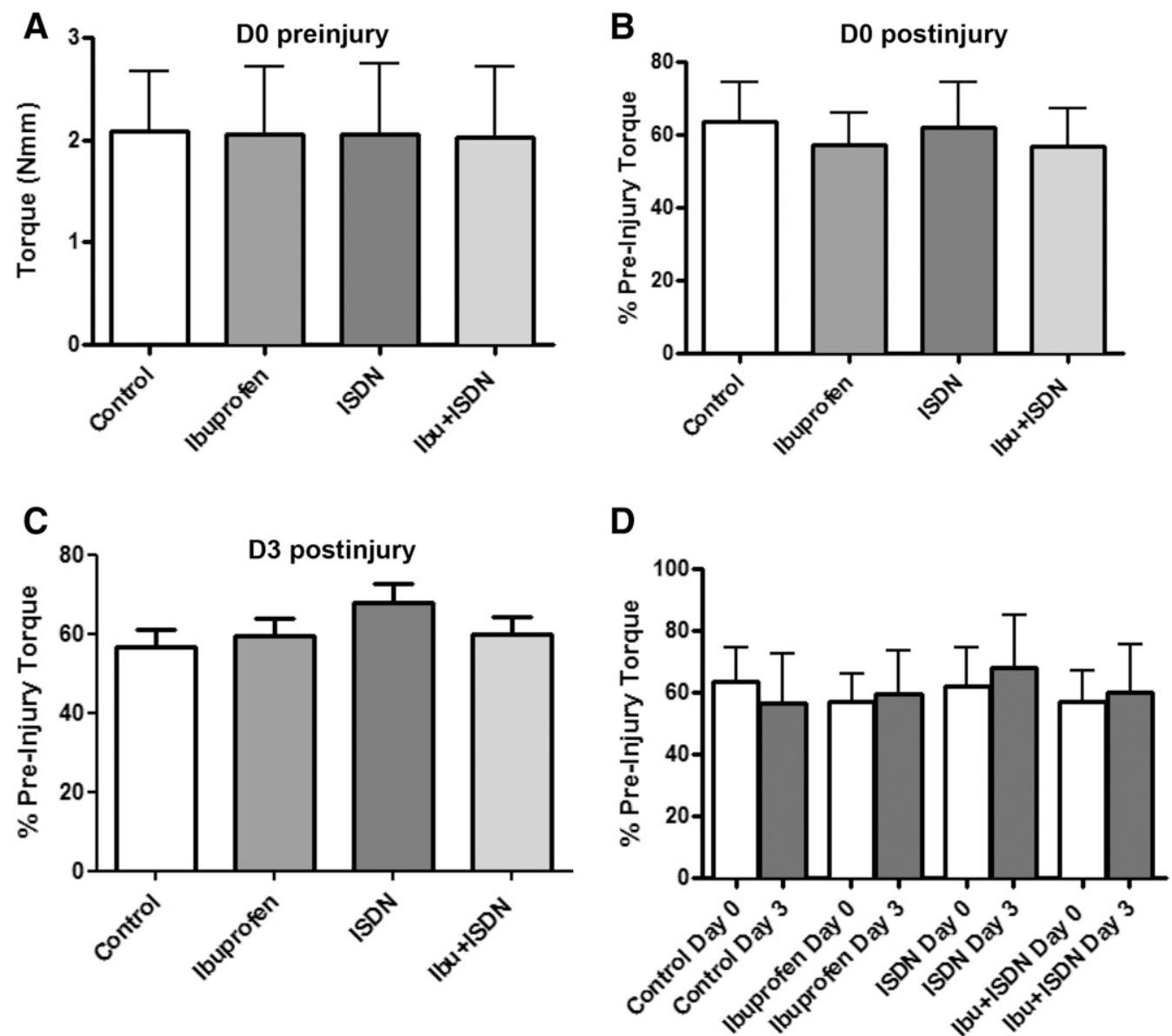

Fig. 2. Torque measurements in dosed and control mice before and after LSI. Contractile torque was determined from control ( $n=13)$, ibuprofen-treated ( $n=11)$, and ISDN-treated $(n=12)$ mice, as well as from mice treated with both drugs (Ibu + ISDN, $n=13)$. (A) Initial torque levels are not affected by drug dosing. (B) Torque immediately following injury on day 0 shows no effect of the drugs. (C) Torque measured on day 3 indicates no beneficial effect of the drugs in these grouped data. (D) Torque levels from day 0 postinjury and day 3 are directly compared. None of the differences are significant at $P<$ 0.05. Data are means \pm S.D. 

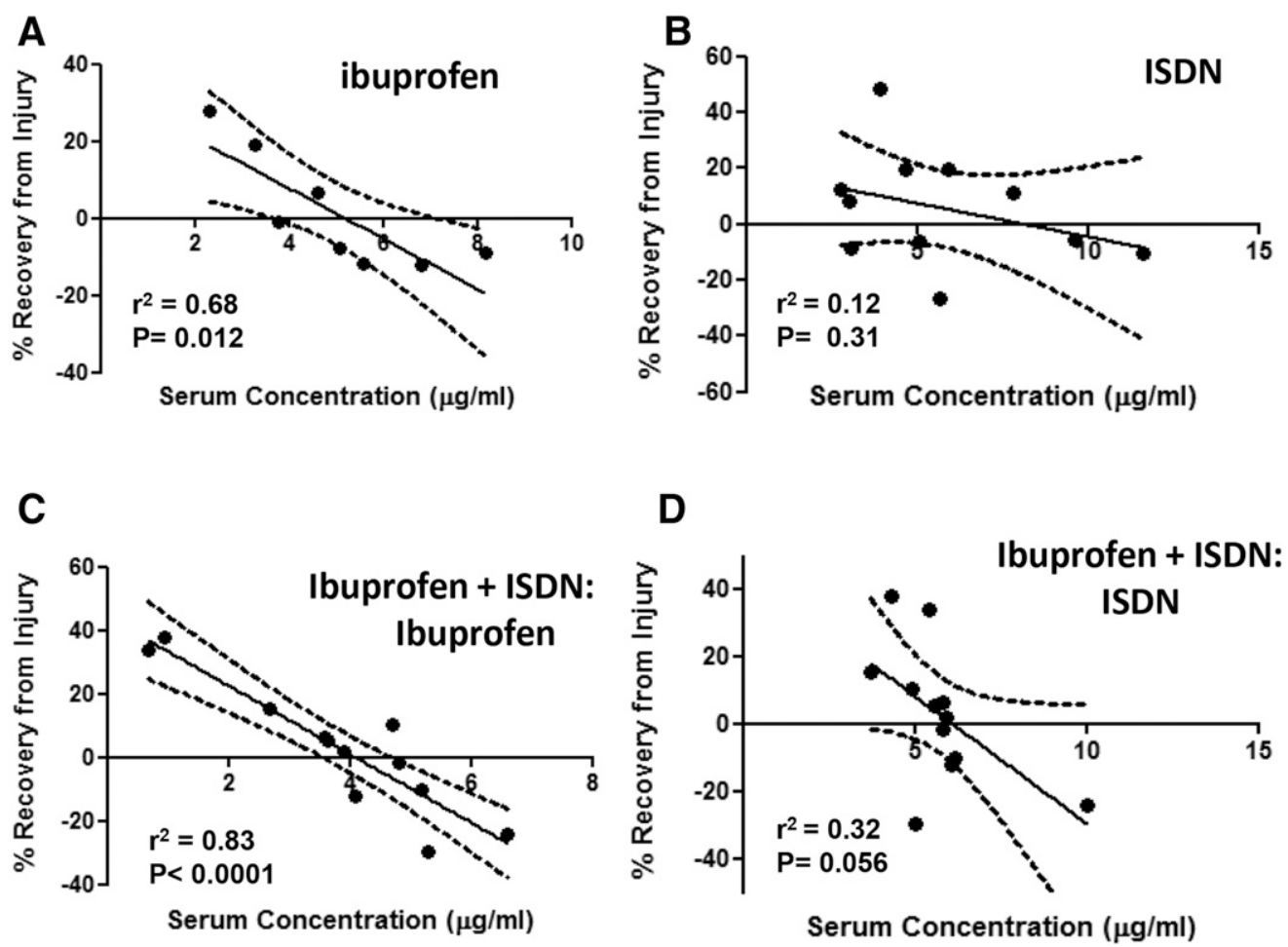

Fig. 3. Torque measurements as a function of serum levels of drugs. Graphs show the relationship between percentage of recovery from LSI on day 3 versus serum concentration of ibuprofen and ISDN, in micrograms per milliliter. (A) Higher ibuprofen levels lead to an inhibited recovery $\left(r^{2}=0.68 ; P=\right.$ 0.012). (B) ISDN at increasing concentrations does not inhibit recovery significantly. (C and D) Ibuprofen serum levels (C) and ISDN serum levels (D) in ibuprofen + ISDN-treated animals give similar results. Even in the presence of ISDN, higher levels of ibuprofen significantly inhibit the ability of the muscle to recover $\left(r^{2}=0.83 ; P<0.0001\right)$, but higher levels of ISDN do not. Lines are best fits by linear regression. Dashed curves represent the $95 \%$ confidence interval of the best-fit line.

trended to higher levels of macrophage infiltration, these differences were not statistically significant (Fig. 4C).

As we did with our torque measurements, we subjected our data on necrotic fibers and macrophage numbers to further analysis as a function of drug concentration in the serum. The number of necrotic fibers tended to increase in muscles exposed to higher concentrations of ibuprofen alone (Fig. 5A), but less so in muscles exposed to ibuprofen together with ISDN (Fig. 5C), to ISDN alone (Fig. 5B), or to ISDN together with ibuprofen (Fig. $5 \mathrm{D})$. None of these effects met our criteria for significance, however $(P<0.05)$. Macrophage number also did not vary significantly with the concentration of the drugs in the serum, alone or in combination. These results suggest that, despite the small reduction in necrotic fibers in mice treated with ibuprofen + ISDN (Fig. 4B), increasing circulating levels of ibuprofen or ISDN have no significant effect on either necrosis or macrophage infiltration of injured $\mathrm{A} / \mathrm{J}$ muscles.

\section{Long-Term Studies}

As ibuprofen, but not ISDN, had significant effects in our studies of $\mathrm{A} / \mathrm{J}$ mice, we carried out longer-term studies of the effects of ibuprofen on dysferlinopathic mice. In this case, we examined BlAJ mice, which carry the same altered DYSF gene as the $\mathrm{A} / \mathrm{J}$, but in the C57BL/6J background. Untreated BlAJ mice and C57BL/6J mice served as controls. We maintained BlAJ mice on chow containing ibuprofen with the goal of administering $25 \mathrm{mg} / \mathrm{kg}$ per day for 9 months, starting at 5 months of age. We then assessed overall consumption of the altered diet, body weight, mobility on a rotarod and a treadmill, serum levels of creatine kinase, and the size and composition of the hind limb muscles by MRI.

BlAJ mice fed chow containing ibuprofen consumed more than either BlAJ or C57BL/6J mice fed control chow (Fig. 6A), but body weights did not vary significantly among groups (Fig. $6 \mathrm{~B})$. Ibuprofen levels in the plasma of treated BlAJ mice varied from 0.51 to $5.3 \mu \mathrm{g} / \mathrm{ml}$, with a mean value at 14 months of $1.80 \pm 0.94 \mu \mathrm{g} / \mathrm{ml}(n=12$; data not shown). These values were $\sim 40 \%$ of those we obtained with $\mathrm{A} / \mathrm{J}$ mice (see above). Serum creatine kinase levels were higher in BlAJ mice than in controls, but did not differ with ibuprofen treatment (Fig. 6C). Rotarod performance did not differ between treated and untreated BlAJ mice, nor between BlAJ and C57BL/6 controls (Fig. 6D), but ibuprofen treatment significantly reduced the distance that treated BlAJ could run on a treadmill (Fig. 6E). These results suggest that the ability of BlAJ mice to run extended distances on a treadmill was selectively inhibited by ibuprofen.

Volumetric measurements by MRI revealed a significant genotype difference (C57BL/6J vehicle versus BlAJ vehicle) in the volume of both the gluteus and psoas muscles at 12 months of age, but they failed to reveal any significant effect of ibuprofen (Fig. 7, A and B). MRI of fat and water content in gluteus muscles varied similarly, with higher levels in BlAJ than C57BL/6, but with no effect of ibuprofen treatment (Fig. $7, \mathrm{C}$ and $\mathrm{D}$ ). These results were similar for both male and female mice (data not shown).

Histologic studies of the mice showed no significant differences in the numbers of centrally nucleated fibers between TA 
A
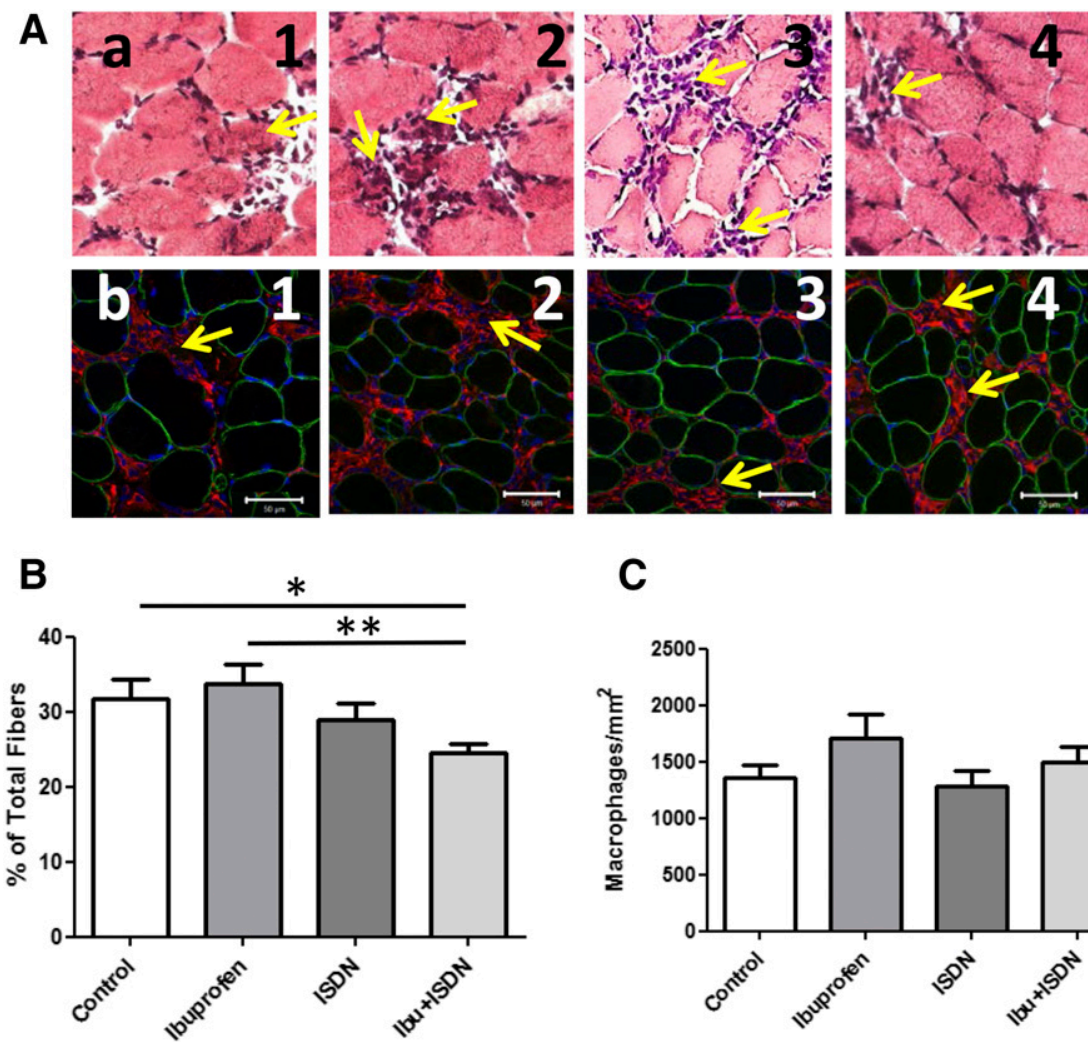

C

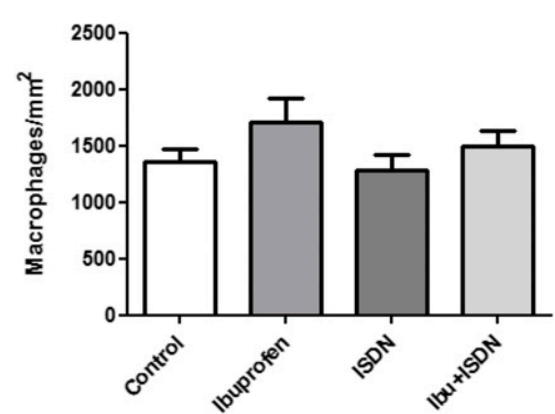

Fig. 4. Histologic analysis of necrotic fibers and macrophages in treated muscles. Morphologic studies used $\mathrm{H} \& \mathrm{E}$ to identify and quantitate necrotic fibers, and anti-CD68 antibodies and immunofluorescence to identify and quantitate macrophages. (A) Stained (a) and immunofluorescent (b) images showing regions of muscles on day 3 after LSI under control conditions (1), with ibuprofen (2), with ISDN (3), and with both drugs (4). (B) Necrotic fibers decrease by a small but significant amount at day 3 following injury in mice treated with ibuprofen + ISND, compared with control and ibuprofen alone. $* * P<0.01 ; * P<0.05$. (C) The extent of macrophage infiltration does not differ significantly among groups. Values shown are mean \pm S.E.M. muscles in BlAJ mice exposed to ibuprofen versus untreated BlAJs, in fiber size, or in fiber size distribution (Fig. 8). Similarly, we found no changes in the frequency of slow fibers in both samples $(<1 \%$, data not shown). Compared with C57BL/6 controls, BlAJ mice and BlAJ mice treated with ibuprofen contained significantly more centrally nucleated fibers, but did not differ in fiber size (Fig. 8). Ibuprofen also had no effect on the number of necrotic fibers or macrophages
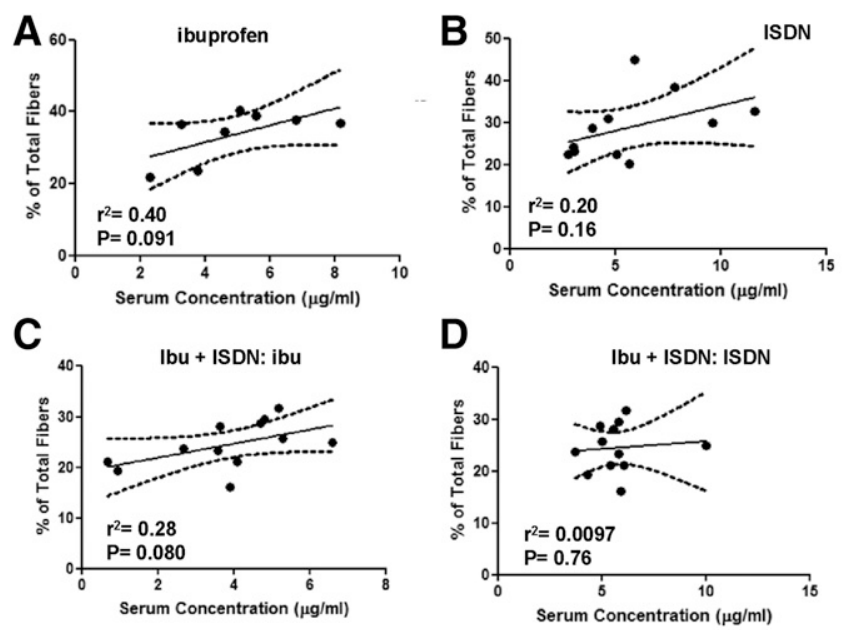

\section{Necrotic Fibers}

in BlaJ TA muscles, which were elevated compared with C57BL/6J controls (Fig. 8).

\section{Discussion}

Inflammation has been proposed as an important factor in promoting the regeneration of muscle after injury and in the loss of function of muscle in the muscular dystrophies

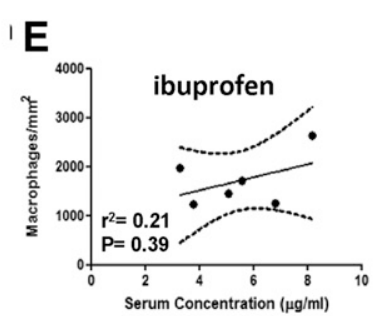

G

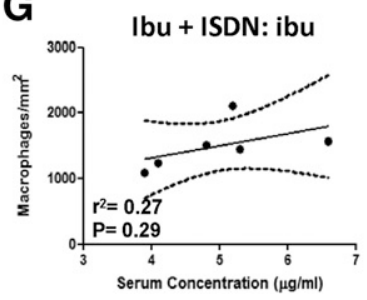

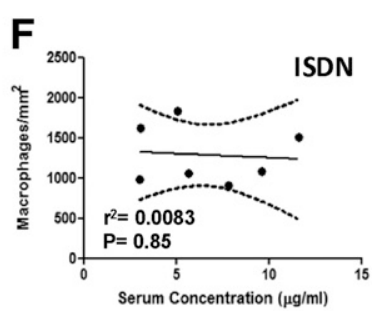

H

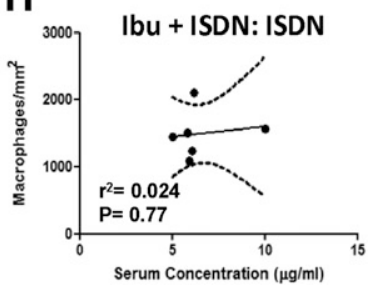

Fig. 5. Necrotic fibers and macrophages quantitated as a function of drug levels in serum. As in Fig. 3, but for the values for necrotic fibers and macrophages measured as in Fig. 4. (A-D) Data for necrotic fibers show that increasing concentrations of ibuprofen are associated with a trend to increased necrosis (A). (E-H) Ibuprofen tends to increase macrophage infiltration to a small extent at higher concentrations with or without ISDN. None of the changes shown reach significance, however. Lines are best fits by linear regression. Dashed curves represent the $95 \%$ confidence interval of the best-fit line. 

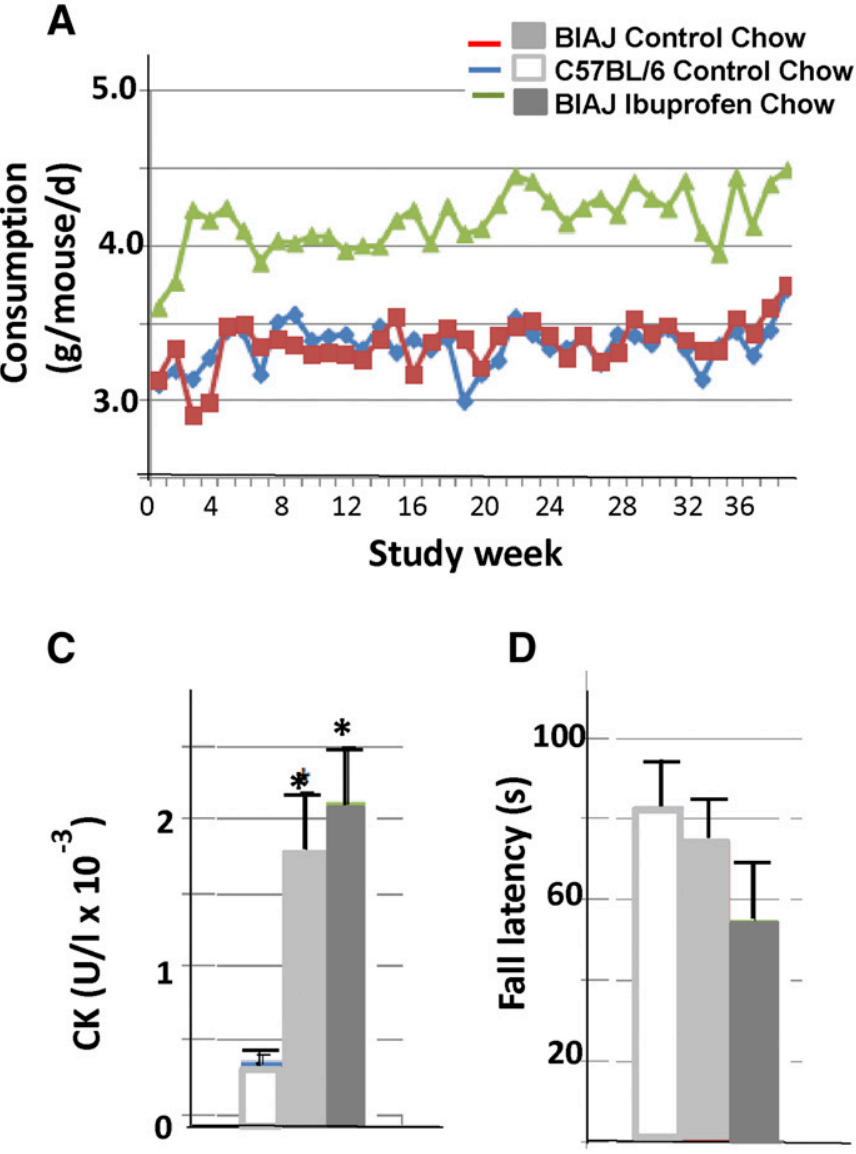

(e.g., Wenzel et al., 2005; Tidball, 2011; Rosenberg et al., 2015; Schiaffino et al., 2017). Clinical and preclinical studies have therefore addressed the possible benefits of antiinflammatories, including steroids, such as prednisone and VPB15 (Griggs et al., 2013; Heier et al., 2013; Matthews et al., 2016), and nonsteroidal drugs, such as ibuprofen (Brunelli et al., 2007; Sciorati et al., 2010). The effectiveness of these drugs can vary with the specific type of muscular dystrophy, however. For example, prednisone and deflazacort have been used extensively in patients with DMD, but they have little or no benefit for individuals with limb girdle muscular dystrophies, including dysferlinopathies (Hussein et al., 2006; Pimentel et al., 2008; Walter et al., 2013). In preclinical studies, ibuprofen has been tested with and without the NO donor, ISDN, with murine models of DMD, a dystrophinopathy, and LGMD2D $\alpha$-sarcoglycanopathy. The two drugs provided synergistic beneficial effects on skeletal muscle phenotypes (Brunelli et al., 2007; Sciorati et al., 2010).

Based on these observations, we tested the effects of ibuprofen and ISDN on A/J mice, which lack dysferlin and therefore serve as a murine model of LGMD2B/MMD1. We subjected the hind limb dorsiflexor muscles of $\mathrm{A} / \mathrm{J}$ mice to large strain lengthening contractions and then measured the effects of the two drugs, introduced singly or together in the chow, on the recovery of muscle structure and function. We also assessed muscle volumes and two measures of muscle function, rotarod balancing and treadmill running, in dysferlin-deficient BlAJ mice maintained on ibuprofen for 9 months. We measured the levels of drugs in the sera of mice

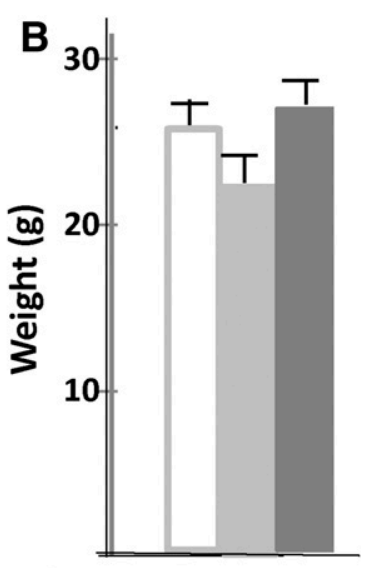

Fig. 6. Long-term dosing of BlAJ mice with ibuprofen: effects on body weight, creatine kinase, rotarod performance, and treadmill running. (A) Food consumption by BlAJ mice fed with chow containing ibuprofen (green), BlAJ mice fed control chow (red), and C57BL/6J mice fed control chow (blue). The $y$-axis in this panel is curtailed. The results show that ibuprofen stimulates food consumption in BlAJ mice. (B) Body weights of mice at 14 months of age. Chow containing ibuprofen has no significant effect on body weight of BlAJ mice (dark gray) compared with BlAJ (light gray) and C57BL/6J (white) mice on the control diet. The same shading is used in (C-E). (C) Plasma levels of creatine kinase (CK) are significantly elevated in BlAJ mice compared with $\mathrm{C} 57 \mathrm{BL} / 6 \mathrm{~J}$ with or without ibuprofen $\left({ }^{*} P<0.05\right)$, but are not significantly altered by ibuprofen. (D) Rotarod performance is not significantly different between BlAJ and C57BL/6J mice, nor is it significantly affected by ibuprofen. (E) BlAJ and C57BL/6J mice run equally well on a treadmill, but the performance of BlAJ mice is significantly impaired by ibuprofen in the chow $(* P<0.05)$. at the termination of both sets of experiments. ISDN had no detectable effect on dysferlinopathic A/J mouse muscle. Furthermore, pharmacological doses of ibuprofen were deleterious to both $\mathrm{A} / \mathrm{J}$ and BlAJ mice, reducing their ability to recover from injury and to run on a treadmill, respectively. Thus, the response of dysferlinopathic mice to these drugs, and to ibuprofen, in particular, is quite different from the responses of mice lacking dystrophin or $\alpha$-sarcoglycan.

We have studied A/J muscle extensively both in vivo and in vitro and have used large strain lengthening contractions in vivo to distinguish its dysferlin-null phenotype from that of several strains of control mice (Roche et al., 2012). Contractile force is lost in A/J muscles immediately following LSI and remains low through day 3 , whereas controls, which are affected equally by injury, recover nearly all contractile activity in this period (Roche et al., 2008, 2010). A/J muscles respond to LSI over the same period by undergoing necrosis and inflammation (Roche et al., 2008, 2010), with the onset of inflammation temporally following that of necrosis in most respects (Roche et al., 2015). Drugs that protect A/J muscle against damage by LSI should therefore significantly improve the recovery of contractile force, as well as reduce necrosis and inflammation, by day 3 postinjury (e.g., Kerr et al., 2013). Our results indicate that ibuprofen, used with or without ISDN, affects the recovery of contractile activity after LSI in a dosedependent manner.

Dosing A/J mice to achieve pharmacologically effective levels of ibuprofen and ISDN was challenging. Although treated and control $\mathrm{A} / \mathrm{J}$ mice consumed the same amounts of 

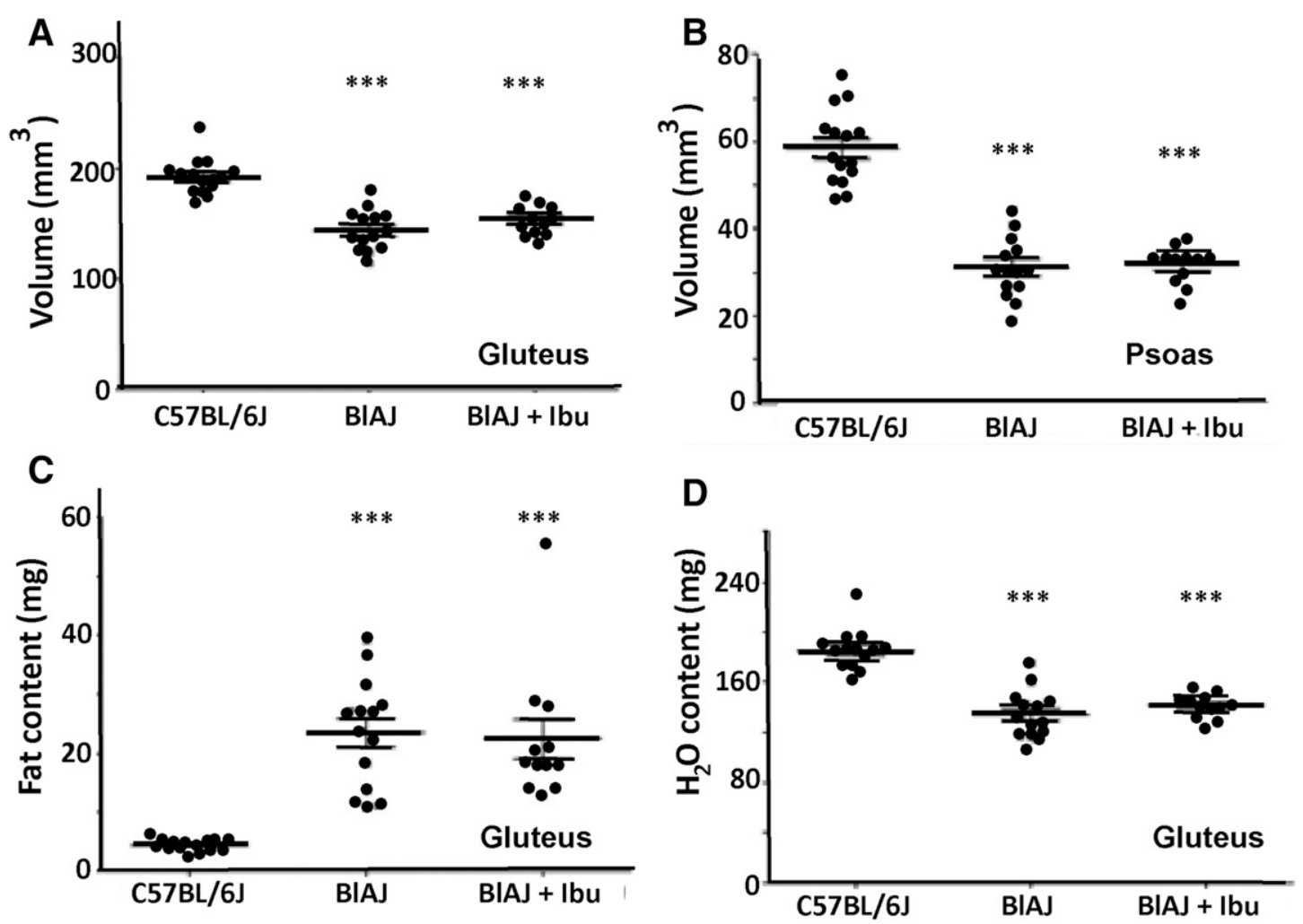

Fig. 7. Volumes and composition of hind limb muscles after long-term treatment with ibuprofen. Volumes and fat and water contents were measured by MRI when mice were 12 months of age. (A and B) Volumes of the gluteus (A) and psoas (B) muscles were significantly reduced in the BlAJ mice compared with C57BL/6J controls, but were not affected by ibuprofen. (C and D) Fat (C) and water (D) contents of gluteus muscles elevated (fat) or diminished (water) in BlAJ mice compared with C57BL/6J controls, but were not affected by ibuprofen. ***Indicate $P<0.001$ for differences between C57BL/6 and BlAJ, with or without ibuprofen treatment.

chow and were equivalent in weight throughout the protocol, they ate less than expected based on previous studies (Bachmanov et al., 2002). The amount of drug that we could detect in the serum varied considerably, and was undetectable in some mice fed with chows containing lower doses of ibuprofen. We therefore used chows with different concentrations of ISDN and ibuprofen to determine the optimal values, and to obtain a range of results that we could analyze as a function of the serum level of each. This analysis revealed that as ibuprofen in the serum approached pharmacologically effective concentrations ( $\geq 5 \mathrm{mg} / \mathrm{ml}$ serum), it inhibited recovery from LSI by $\sim 20 \%$. Notably, concentrations of ibuprofen that were well below pharmacologically effective levels showed small but significant increases in recovery. ISDN showed no significant effects at any serum concentration, although the results trended toward a loss in function as serum levels of ISDN increased. Changes in necrotic fibers and inflammatory cells in injured muscles were smaller, but ibuprofen consistently showed a trend toward greater necrosis and inflammation at higher serum concentrations. The strong correlation of ibuprofen concentrations with torque loss at day 3 after injury suggests that the effects of ibuprofen on the recovery of contractile force were at least partially independent of its anti-inflammatory activity.

We conducted our long-term study of the effects of ibuprofen on BlAJ mice, as they carry the $\mathrm{A} / \mathrm{J}$ variant of the $D y s f$ gene in the $\mathrm{C} 57 \mathrm{BL} / 6 \mathrm{~J}$ background, and, unlike $\mathrm{A} / \mathrm{J}$ mice, they are, quite active, undergo significant muscle pathology in the time frame of our studies, and do not show as much variability in food consumption. This may be due to the fact that in our colonies they are much more active, consistent with earlier reports showing greater activity of $\mathrm{C} 57 \mathrm{BL} / 6$ than $\mathrm{A} / \mathrm{J}$ mice (Wax, 1977; Ingram et al., 1981; but see Lightfoot et al., 2004). The single dose of ibuprofen that we assayed in the chow gave values that were somewhat lower than those reached in $\mathrm{A} / \mathrm{J}$ mice, consistent with a faster clearance rate of the drug from BlAJ mice. Our experiments failed to show significant changes in the volumes, fat contents, or histology of BlAJ skeletal muscles with ibuprofen treatment. These results suggest that neither edema nor fatty infiltration, which can accompany the dystrophic phenotype, is significantly altered by the drug. It is of course possible that higher doses of ibuprofen could adversely affect these measures. Nevertheless, these relatively low doses of ibuprofen reduced the ability of BlAJ mice to run on a treadmill by $\sim 40 \%$ (Fig. $6 \mathrm{E}$ ). Thus, even at low levels, ibuprofen administered over a period of many months can have detrimental effects on muscle function, consistent with our observations in $\mathrm{A} / \mathrm{J}$ mice.

The action of ibuprofen and other common nonsteroidal anti-inflammatory drugs on skeletal muscle has been extensively examined (see Schoenfeld, 2012, for a review). Through its action as a cyclooxygenase inhibitor, ibuprofen reduces inflammation and pain, and may thereby promote recovery of muscle function in individuals with chronic conditions, such as osteoarthritis. Ibuprofen has also been reported to have deleterious effects on muscle, including inhibiting intracellular signaling (Markworth et al., 2014) and protein synthesis (Trappe et al., 2002) required for muscle growth and regeneration (see 


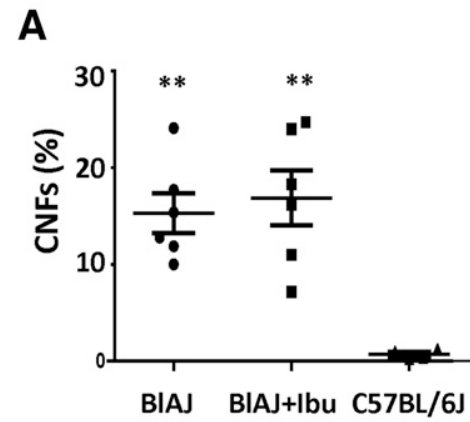

D

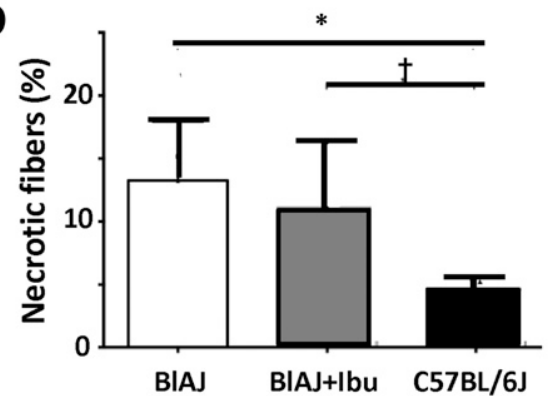

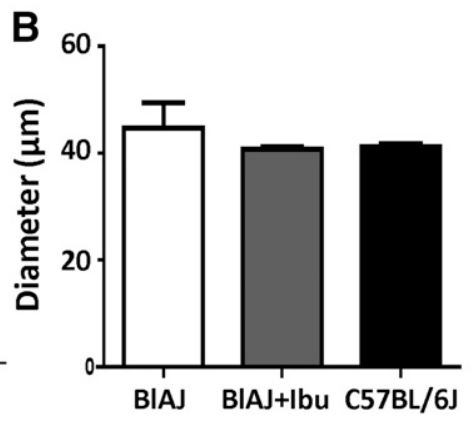
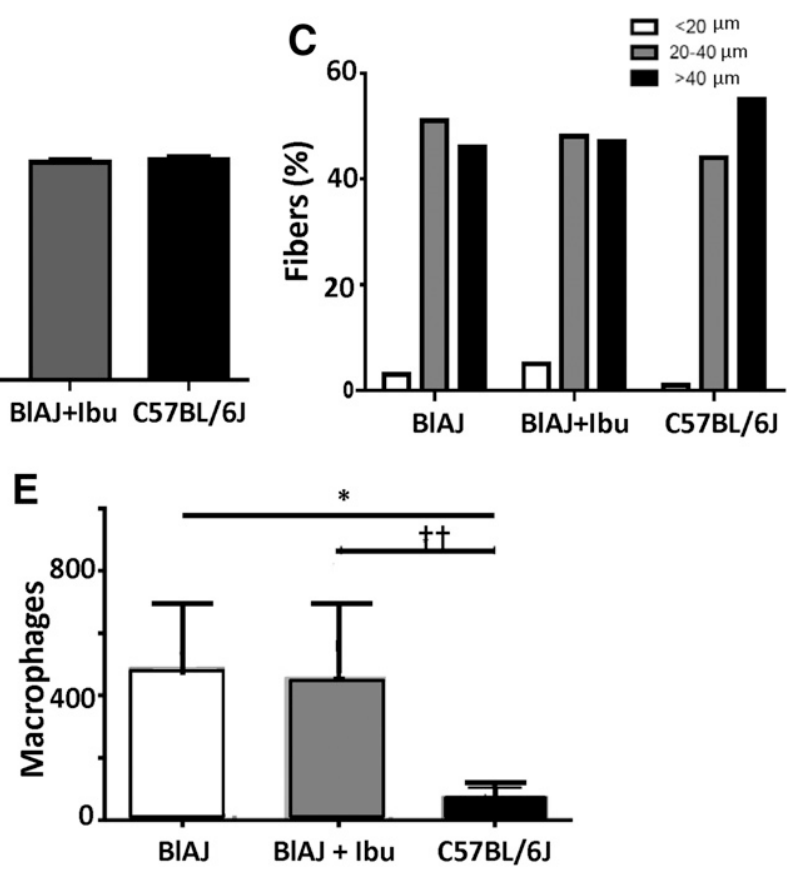

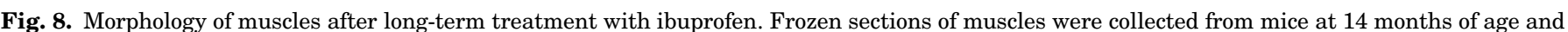

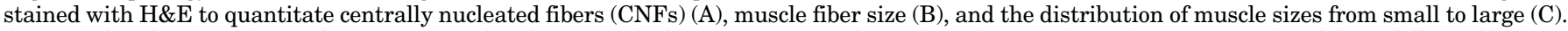

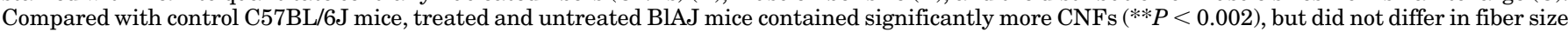

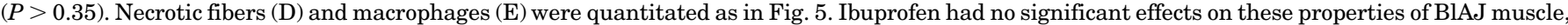
which were, however, significantly different from those in C57BL/6J controls $(* P<0.01 ; \dagger \dagger P<0.02 ; \dagger P<0.05)$.

also Ho et al., 2017; but see Krentz et al., 2008; Mackey et al., 2016). These different effects may be due in part to the response of different cell types to the drugs, as well as to different levels of ibuprofen, just as we have observed a range of effects of ibuprofen on muscle activity as a function of drug concentration.

Like ibuprofen, NO donors such as ISDN can have either beneficial or detrimental effects, depending on the conditions of the tissue under study. They were examined in muscle lacking dystrophin or $\alpha$-sarcoglycan in part because the absence of these proteins leads to a decrease in NO production by neuronal NO synthase (Wozniak and Anderson, 2009), one of the many proteins that can associate with the dystrophin-glycoprotein complex (Brenman et al., 1995; but see Chang et al., 1996). It is therefore not surprising that ISDN produced positive results with $m d x$ and $S c g a^{-/-}$mice. Although dysferlin's role in skeletal muscle is still controversial, one of the effects of its absence in muscle is increased oxidative stress (Terrill et al., 2013). ISDN might therefore be expected to have little or no beneficial effect on $\mathrm{A} / \mathrm{J}$ muscle, consistent with our results. It is perhaps surprising that the higher than normal levels of NO generated by ISDN, which would enhance oxidative stress, in fact had no detrimental effect on A/J muscles. Assays of nitrosylation of $\mathrm{A} / \mathrm{J}$ muscle proteins could address the possibility that NO levels might indeed be abnormally high, but have little effect on muscle structure or function in our experiments.

In conclusion, our studies of dysferlin-null $\mathrm{A} / \mathrm{J}$ muscles subjected to injury by large strain lengthening contractions show that ISDN has no detectable beneficial effect, and that ibuprofen at pharmacologically effective doses inhibits the recovery of contractile strength. Our studies of the effects of long-term exposure of BlAJ mice to ibuprofen further indicate that the drug, even at lower than pharmacologically beneficial doses, can impair muscle function. Our results with dysferlinopathic mice differ from those with murine models of dystrophinopathy and $\alpha$-sarcoglycanopathy. Although our experiments used two different murine strains over very different time frames and in very different assays, and so should be interpreted with caution, our findings suggest that individuals with LGMD2B or MMD1 avoid the use of pharmacological doses of ibuprofen, pending evidence to the contrary.

\section{Acknowledgments}

We thank Joseph A. Roche (Assistant Professor, Physical Therapy Program, Wayne State University) for developing the physiological and histological assays described in this paper, for suggestions regarding the experiments, and for training A.F.C. and J.G. to perform these assays independently. We also thank S.M. and A.O'.N. for maintaining the colony of $\mathrm{A} / \mathrm{J}$ mice.

\section{Authorship Contributions}

Participated in research design: Ahtoniemi, Windish, Williams, Albrecht, Bloch.

Conducted experiments: Collier, Gumerson, Manne, O’Neill, Lehtimäki, Puoliväli, Ahtoniemi.

Performed data analysis: Jones, Kane Lehtimaki, Puolivali, Bloch. Contributed to the writing of the manuscript: Bloch, Kane, Lehtimäki, Puoliväli, Williams, Windish, Gumerson.

\section{References}

Angelini C, Peterle E, Gaiani A, Bortolussi L, and Borsato C (2011) Dysferlinopathy course and sportive activity: clues for possible treatment. Acta Myol 30:127-132 Araujo KP, Bonuccelli G, Duarte CN, Gaiad TP, Moreira DF, Feder D, Belizario JE, Miglino MA, Lisanti MP, and Ambrosio CE (2013) Bortezomib (PS-341) treatment decreases inflammation and partially rescues the expression of the dystrophinglycoprotein complex in GRMD dogs. PLoS One 8:e61367.

Bachmanov AA, Reed DR, Beauchamp GK, and Tordoff MG (2002) Food intake, water intake, and drinking spout side preference of 28 mouse strains. Behav Genet 32:435-443. 
Biondi O, Villemeur M, Marchand A, Chretien F, Bourg N, Gherardi RK, Richard I, and Authier F-J (2013) Dual effects of exercise in dysferlinopathy. Am J Pathol 182:2298-2309.

Brenman JE, Chao DS, Xia H, Aldape K, and Bredt DS (1995) Nitric oxide synthase complexed with dystrophin and absent from skeletal muscle sarcolemma in Duchenne muscular dystrophy. Cell 82:743-752.

Brunelli S, Sciorati C, D’Antona G, Innocenzi A, Covarello D, Galvez BG, Perrotta C, Monopoli A, Sanvito F, Bottinelli R, et al. (2007) Nitric oxide release combined with nonsteroidal antiinflammatory activity prevents muscular dystrophy pathology and enhances stem cell therapy. Proc Natl Acad Sci USA 104:264-269.

Carvalho SC, Apolinário LM, Matheus SM, Santo Neto H, and Marques MJ (2013) EPA protects against muscle damage in the mdx mouse model of Duchenne muscular dystrophy by promoting a shift from the M1 to M2 macrophage phenotype. $J$ Neuroimmunol 264:41-47.

Chang WJ, Iannaccone ST, Lau KS, Masters BS, McCabe TJ, McMillan K, Padre RC, Spencer MJ, Tidball JG, and Stull JT (1996) Neuronal nitric oxide synthase and dystrophin-deficient muscular dystrophy. Proc Natl Acad Sci USA 93:9142-9147.

Cossu MV, Cattaneo D, Fucile S, Pellegrino P, Baldelli S, Cozzi V, Capetti A, and Clementi E (2014) Combined isosorbide dinitrate and ibuprofen as a novel therapy for muscular dystrophies: evidence from Phase I studies in healthy volunteers. Drug Des Devel Ther 8:411-419.

Drachman DB, Toyka KV, and Myer E (1974) Prednisone in Duchenne muscular dystrophy. Lancet 2:1409-1412.

Ermolova NV, Martinez L, Vetrone SA, Jordan MC, Roos KP, Sweeney HL, and Spencer MJ (2014) Long-term administration of the TNF blocking drug Remicade (cV1q) to mdx mice reduces skeletal and cardiac muscle fibrosis, but negatively impacts cardiac function. Neuromuscul Disord 24:583-595.

Gallardo E, Rojas-García R, de Luna N, Pou A, Brown RH, Jr, and Illa I (2001) Inflammation in dysferlin myopathy: immunohistochemical characterization of 13 patients. Neurology 57:2136-2138.

Gordon BS, Delgado-Diaz DC, Carson J, Fayad R, Wilson LB, and Kostek MC (2014) Resveratrol improves muscle function but not oxidative capacity in young $\mathrm{mdx}$ mice. Can J Physiol Pharmacol 92:243-251.

Griggs RC, Herr BE, Reha A, Elfring G, Atkinson L, Cwik V, McColl E, Tawil R, Pandya S, McDermott MP, et al. (2013) Corticosteroids in Duchenne muscular dystrophy: major variations in practice. Muscle Nerve 48:27-31.

Grounds MD and Torrisi J (2004) Anti-TNFalpha (Remicade) therapy protects dystrophic skeletal muscle from necrosis. FASEB $J$ 18:676-682.

Heier CR, Damsker JM, Yu Q, Dillingham BC, Huynh T, Van der Meulen JH, Sali A, Miller BK, Phadke A, Scheffer L, et al. (2013) VBP15, a novel anti-inflammatory and membrane-stabilizer, improves muscular dystrophy without side effects. EMBO Mol Med 5:1569-1585.

Ho ATV, Palla AR, Blake MR, Yucel ND, Wang YX, Magnusson KEG, Holbrook CA, Kraft PE, Delp SL, and Blau HM (2017) Protaglandin E2 is essential for efficacious skeletal muscle stem-cell function, augmenting regeneration and strength. Proc Natl Acad Sci USA 114:6675-6684

Hussein MR, Hamed SA, Mostafa MG, Abu-Dief EE, Kamel NF, and Kandil MR (2006) The effects of glucocorticoid therapy on the inflammatory and dendritic cells in muscular dystrophies. Int J Exp Pathol 87:451-461.

Ingram DK, London ED, Reynolds MA, Waller SB, and Goodrick CL (1981) Differential effects of age on motor performance in two mouse strains. Neurobiol Aging 2: 221-227.

Kerr JP, Ziman AP, Mueller AL, Muriel JM, Kleinhans-Welte E, Gumerson JD, Vogel SS, Ward CW, Roche JA, and Bloch RJ (2013) Dysferlin stabilizes stress-induced $\mathrm{Ca}^{2+}$ signaling in the transverse tubule membrane. Proc Natl Acad Sci USA 110:20831-20836.

Klinge L, Dean AF, Kress W, Dixon P, Charlton R, Müller JS, Anderson LV, Straub V, Barresi R, Lochmüller H, et al. (2008) Late onset in dysferlinopathy widens the clinical spectrum. Neuromuscul Disord 18:288-290.

Krentz JR, Quest B, Farthing JP, Quest DW, and Chilibeck PD (2008) The effects of ibuprofen on muscle hypertrophy, strength, and soreness during resistance training. Appl Physiol Nutr Metab 33:470-475.

Lightfoot JT, Turner MJ, Daves M, Vordermark A, and Kleeberger SR (2004) Genetic influence on daily wheel running activity level. Physiol Genomics 19:270-276.

Liu J, Aoki M, Illa I, Wu C, Fardeau M, Angelini C, Serrano C, Urtizberea JA, Hentati F, Hamida MB, et al. (1998) Dysferlin, a novel skeletal muscle gene, is mutated in Miyoshi myopathy and limb girdle muscular dystrophy. Nat Genet 20:31-36.

Lostal W, Bartoli M, Roudaut C, Bourg N, Krahn M, Pryadkina M, Borel P, Suel L, Roche JA, Stockholm D, et al. (2012) Lack of correlation between outcomes of membrane repair assay and correction of dystrophic changes in experimental therapeutic strategy in dysferlinopathy. PLoS One 7:e38036.

Lovering RM, Roche JA, Bloch RJ, and De Deyne PG (2007) Recovery of function in skeletal muscle following 2 different contraction-induced injuries. Arch Phys Med Rehabil 88:617-625.

Mackey AL, Rasmussen LK, Kadi F, Schjerling P, Helmark IC, Ponsot E, Aagaard P, Durigan JL, and Kjaer M (2016) Activation of satellite cells and the regeneration of human skeletal muscle are expedited by ingestion of nonsteroidal antiinflammatory medication. FASEB $J$ 30:2266-2281.

Manning J, Kulbida R, Rai P, Jensen L, Bouma J, Singh SP, O'Malley D, and Yilmazer-Hanke D (2014) Amitriptyline is efficacious in ameliorating muscle inflammation and depressive symptoms in the mdx mouse model of Duchenne muscular dystrophy. Exp Physiol 99:1370-1386.

Mariano A, Henning A, and Han R (2013) Dysferlin-deficient muscular dystrophy and innate immune activation. FEBS $J$ 280:4165-4176.

Markworth JF, Vella LD, Figueiredo VC, and Cameron-Smith D (2014) Ibuprofen treatment blunts early translational signaling responses in human skeletal muscle following resistance exercise. J Appl Physiol (1985) 117:20-28.
Matthews E, Brassington R, Kuntzer T, Jichi F, and Manzur AY (2016) Corticosteroids for the treatment of Duchenne muscular dystrophy. Cochrane Database Syst Rev 2016:CD003725.

McNally EM, Ly CT, Rosenmann H, Mitrani Rosenbaum S, Jiang W, Anderson LV, Soffer D, and Argov Z (2000) Splicing mutation in dysferlin produces limb-girdle muscular dystrophy with inflammation. Am J Med Genet 91:305-312.

Mendell JR, Goemans N, Lowes LP, Alfano LN, Berry K, Shao J, Kaye EM, and Mercuri E; Eteplirsen Study Group and Telethon Foundation DMD Italian Network (2016) Longitudinal effect of eteplirsen versus historical control on ambulation in Duchenne muscular dystrophy. Ann Neurol 79:257-271.

Mendell JR, Rodino-Klapac LR, Sahenk Z, Roush K, Bird L, Lowes LP, Alfano L, Gomez AM, Lewis S, Kota J, et al.; Eteplirsen Study Group (2013) Eteplirsen for the treatment of Duchenne muscular dystrophy. Ann Neurol 74:637-647.

Nagaraju K, Rawat R, Veszelovszky E, Thapliyal R, Kesari A, Sparks S, Raben N Plotz P, and Hoffman EP (2008) Dysferlin deficiency enhances monocyte phagocytosis: a model for the inflammatory onset of limb-girdle muscular dystrophy $2 \mathrm{~B}$. Am J Pathol 172:774-785.

Nelson CE, Hakim CH, Ousterout DG, Thakore PI, Moreb EA, Castellanos Rivera RM, Madhavan S, Pan X, Ran FA, Yan WX, et al. (2016) In vivo genome editing improves muscle function in a mouse model of Duchenne muscular dystrophy. Science 351:403-407.

Nigro V and Savarese M (2014) Genetic basis of limb-girdle muscular dystrophies: the 2014 update. Acta Myol 33:1-12.

Pimentel LH, Alcântara RN, Fontenele SM, Costa CM, and Gondim F de A (2008) Limb-girdle muscular dystrophy type 2B mimicking polymyositis. Arq Neuropsiquiatr 66:80-82

Quattrocelli M, Salamone IM, Page PG, Warner JL, Demonbreun AR, and McNally EM (2017) Intermittent glucocorticoid dosing improves muscle repair and function in mice with limb-girdle muscular dystrophy. Am J Pathol 187:2520-2535.

Roche JA, Lovering RM, and Bloch RJ (2008) Impaired recovery of dysferlin-null skeletal muscle after contraction-induced injury in vivo. Neuroreport 19 1579-1584.

Roche JA, Lovering RM, Roche R, Ru LW, Reed PW, and Bloch RJ (2010) Extensive mononuclear infiltration and myogenesis characterize recovery of dysferlin-nul skeletal muscle from contraction-induced injuries. Am J Physiol Cell Physiol 298: C298-C312.

Roche JA, Ru LW, and Bloch RJ (2012) Distinct effects of contraction-induced injury in vivo on four different murine models of dysferlinopathy. $J$ Biomed Biotechnol 2012:134031.

Roche JA, Tulapurkar ME, Mueller AL, van Rooijen N, Hasday JD, Lovering RM, and Bloch RJ (2015) Myofiber damage precedes macrophage infiltration after in vivo injury in dysferlin-deficient A/J mouse skeletal muscle. Am J Pathol 185 $1686-1698$

Rosenberg AS, Puig M, Nagaraju K, Hoffman EP, Villalta SA, Rao VA, Wakefield LM, and Woodcock J (2015) Immune-mediated pathology in Duchenne muscular dystrophy. Sci Transl Med 7:299rv4.

Schiaffino S, Pereira MG, Ciciliot S, and Rovere-Querini P (2017) Regulatory T cells and skeletal muscle regeneration. FEBS $J$ 284:517-524

Schoenfeld BJ (2012) The use of nonsteroidal anti-inflammatory drugs for exerciseinduced muscle damage: implications for skeletal muscle development. Sports Med 42:1017-1028.

Sciorati C, Buono R, Azzoni E, Casati S, Ciuffreda P, D'Angelo G, Cattaneo D, Brunelli S, and Clementi E (2010) Co-administration of ibuprofen and nitric oxide is an effective experimental therapy for muscular dystrophy, with immediate applicability to humans. Br J Pharmacol 160:1550-1560.

Tabebordbar M, Zhu K, Cheng JKW, Chew WL, Widrick JJ, Yan WX, Maesner C, Wu EY, Xiao R, Ran FA, et al. (2016) In vivo gene editing in dystrophic mouse muscle and muscle stem cells. Science 351:407-411.

Terrill JR, Radley-Crabb HG, Iwasaki T, Lemckert FA, Arthur PG, and Grounds MD (2013) Oxidative stress and pathology in muscular dystrophies: focus on protein thiol oxidation and dysferlinopathies. FEBS $J$ 280:4149-4164.

Tidball JG (2011) Mechanisms of muscle injury, repair, and regeneration. Compr Physiol 1:2029-2062.

Trappe TA, White F, Lambert CP, Cesar D, Hellerstein M, and Evans WJ (2002) Effect of ibuprofen and acetaminophen on postexercise muscle protein synthesis. Am J Physiol Endocrinol Metab 282:E551-E556.

Walter MC, Reilich P, Thiele S, Schessl J, Schreiber H, Reiners K, Kress W, MüllerReible C, Vorgerd M, Urban P, et al. (2013) Treatment of dysferlinopathy with deflazacort: a double-blind, placebo-controlled clinical trial. Orphanet J Rare Dis 8 : 26.

Wax TM (1977) Effects of age, strain, and illumination intensity on activity and selfselection of light-dark schedules in mice. J Comp Physiol Psychol 91:51-62.

Wenzel K, Zabojszcza J, Carl M, Taubert S, Lass A, Harris CL, Ho M, Schulz H, Hummel O, Hubner N, et al. (2005) Increased susceptibility to complement attack due to down-regulation of decay-accelerating factor/CD55 in dysferlin-deficient muscular dystrophy. J Immunol 175:6219-6225.

Wozniak AC and Anderson JE (2009) The dynamics of the nitric oxide releasetransient from stretched muscle cells. Int J Biochem Cell Biol 41:625-631.

Yin X, Wang Q, Chen T, Niu J, Ban R, Liu J, Mao Y, and Pu C (2015) CD4+ cells, macrophages, MHC-I and C5b-9 involve the pathogenesis of dysferlinopathy. Int $J$ Clin Exp Pathol 8:3069-3075.

Address correspondence to: Dr. Robert J. Bloch, Department of Physiology, University of Maryland School of Medicine, 655 West Baltimore Street, Baltimore, MD 21201. E-mail: rbloch@som.umaryland.edu 